\title{
Predatory activity of the fungi Duddingtonia flagrans, Monacrosporium thaumasium, Monacrosporium sinense and Arthrobotrys robusta on Angiostrongylus vasorum first-stage larvae
}

\author{
F.R. Braga ${ }^{1}$, R.O. Carvalho ${ }^{1}$, J.M. Araujo ${ }^{1}$, A.R. Silva ${ }^{1}$, \\ J.V. Araújo ${ }^{1 * \dagger}$, W.S. Lima ${ }^{2}$, A.O. Tavela ${ }^{1}$ and S.R. Ferreira ${ }^{1}$ \\ ${ }^{1}$ Departamento de Veterinária, Universidade Federal de Viçosa, Viçosa, \\ MG 36570-000, Brazil: ${ }^{2}$ Departamento de Parasitologia, Instituto de \\ Ciências Biológicas, Universidade Federal de Minas Gerais, \\ Belo Horizonte, MG, Brazil
}

(Accepted 18 December 2008; First Published Online 16 February 2009)

\begin{abstract}
Angiostrongylus vasorum is a nematode that parasitizes domestic dogs and wild canids. We compared the predatory capacity of isolates from the predatory fungi Duddingtonia flagrans (AC001), Monacrosporium thaumasium (NF34), Monacrosporium sinense (SF53) and Arthrobotrys robusta (I31) on first-stage larvae $\left(\mathrm{L}_{1}\right)$ of $A$. vasorum under laboratory conditions. $\mathrm{L}_{1} A$. vasorum were plated on $2 \%$ water-agar (WA) Petri dishes marked into $4 \mathrm{~mm}$ diameter fields with the four grown isolates and a control without fungus. Plates of treated groups contained each $1000 \mathrm{~L}_{1}$ A. vasorum and 1000 conidia of the fungal isolates AC001, NF34, SF53 and I31 on $2 \%$ WA. Plates of the control group (without fungus) contained only $1000 \mathrm{~L}_{1} A$. vasorum on $2 \%$ WA. Ten random fields (4 mm diameter) were examined per plate of treated and control groups, every $24 \mathrm{~h}$ for 7 days. Nematophagous fungi were not observed in the control group during the experiment. There was no variation in the predatory capacity among the tested fungal isolates $(P>0.05)$ during the 7 days of the experiment. There was a significant reduction $(P<0.05)$ of $80.3 \%, 74.5 \%, 74.2 \%$ and $71.8 \%$ in the means of A. vasorum $\mathrm{L}_{1}$ recovered from treatments with isolates AC001, NF34, SF53 and I31, respectively, compared to the control without fungi. In this study, the four isolates of predatory fungi were efficient in the in vitro capture and destruction of A. vasorum $\mathrm{L}_{1}$, confirming previous work on the efficiency of nematophagous fungi in the control of nematode parasites of dogs and as a possible alternative method of biological control.
\end{abstract}

\section{Introduction}

Angiostrongylus vasorum (Baillet, 1866) Kamensky, 1905, is a protostrongylid nematode of cosmopolitan distribution. Adult parasites can be found in the right ventricle

*E-mail: jvictor@ufv.br

${ }^{\dagger}$ Scholarship CNPq, Rio de Janeiro, Brazil. and pulmonary arteries and their branches, causing severe consequences to the definitive host. The most common symptoms are cough, breathlessness, exercise intolerance, weight loss, neurological signs, heart failure and death (Ribieri et al., 2001; Oliveira et al., 2005; Saeed et al., 2006). Infection of the definitive host results from the ingestion of infected snails, although paratenic hosts, such as frogs, lizards, mice and rats, may also be ingested by the definitive host (Bolt et al., 1993). 
Angiostrongylus vasorum has a heteroxenic life cycle and several species of terrestrial and aquatic molluscs serve as intermediate hosts. Egg embryonation occurs in the pulmonary arterioles of the definitive host until the development of the first-stage larvae $\left(\mathrm{L}_{1}\right)$ that will hatch and penetrate the alveoli and enter the bronchioles and the bronchi. These $\mathrm{L}_{1}$ migrate to the trachea and are either expelled with pulmonary secretions or swallowed and eliminated with faeces (Patteson et al., 1993; Cury \& Lima, 1995, 2002; Cury et al., 2002). The $\mathrm{L}_{1}$ remain in the faeces or may reach water collection points. Terrestrial or aquatic molluscs are infected by the ingestion of $\mathrm{L}_{1}$ via the digestive tract or by larval penetration through their soft parts (Thiengo, 1996). Within mollusc tissues, larvae develop and become infective or third-stage larvae (Guilhon \& Cens, 1973; Barçante et al., 2003a).

Because of the medical importance of angiostrongyliasis in humans and animals, studies have been carried out to determine the efficacy of treatment with albendazole (Eckert \& Lämmler, 1972). Most anthelmintic drugs are not efficient against this parasite within the definitive host. For this reason, alternative measures that may be used to combat the environmental spread and the infective forms of these parasites are important; such is the case of natural antagonists. These organisms may include different types of fungi, characterized as predators, endoparasites and opportunists. The advantages of their use include: they are not nutritionally demanding, do not require complex growth media, and concentrate their action on the faecal environment and combat free-living larvae (Araújo et al., 2004a).

Until 1964, most fungi were classified as belonging to the genera Arthrobotrys, Dactylis, Dactyella and Trichothecium. Subsequently, several new genera were described, including Duddingtonia, Monacrosporium, Geniculate and Dactylariopsis (Gray, 1987). The vast majority of nematophagous fungi are mitosporic and were formerly classified into the division Deuteromycetes, class Hyphomycetes, order Hyphomycetales and family Moliniaceae. Recently, stages of sexual reproduction of these fungi have been observed for some species that are recognized as belonging to the phylum Ascomycota (Griffin, 1994).

Predatory fungi are certainly the most studied groups and show the greatest potential for biological control (Nordbring-Hertz et al., 2002; Araújo et al., 2007). The species Duddingtonia flagrans, Monacrosporium thaumasium, M. sinense and Arthrobotrys robusta are identified as nematophagous fungi and have been studied for their potential as biological control agents for gastrointestinal nematodes of domestic animals (Araújo et al., 2006, 2008; Campos et al., 2007).

Duddingtonia flagrans is considered the most promising nematode-trapping species for the control of nematodiosis in domestic animals, due to its plentiful production of chlamydospores. These thick-walled spores caused significant larval reduction in faecal cultures and pastures (Rocha et al., 2007). It has predatory action by forming traps characterized by a system of simple adhesive hyphae that produce two types of spores - conidia and chlamydospores - interspersed by mature hyphae, which can be used as a biological control agent in the environment (Braga et al., 2007). Species of the genus
Monacrosporium are characterized by producing a single conidium on each conidiophore and production of adhesive networks, forming septate and branched hyphae, while $M$. sinense produces chlamydospores (Mota et al., 2003; Campos et al., 2007). The species A. robusta presents erect conidiophores, sometimes branched, about $300 \mathrm{~mm}$ in length, having the extremity increased in size, usually carrying six ovoid-shaped conidia, hyaline, sectioned closely to the intermediate region, $18-27 \mathrm{~mm}$ long and $8-12 \mathrm{~mm}$ wide, and capable of producing chlamydospores and adhesive networks for preying on nematodes (Araújo et al., 1998, 2000).

The objective of this work was to compare the in vitro predatory capacity of the fungal species $D$. flagrans, $M$. thaumasium, M. sinense and A. robusta on first-stage larvae of $A$. vasorum.

\section{Material and methods}

\section{Fungi}

Four nematophagous fungal isolates were used in the experiment: D. flagrans (AC001), M. thaumasium (NF34), M. sinense (SF53) and A. robusta (I31). The isolates were originally obtained from soil located in Viçosa, Minas Gerais, Brazil, $20^{\circ} 45^{\prime} 20^{\prime \prime} \mathrm{S}$; $42^{\circ} 52^{\prime} 40^{\prime \prime} \mathrm{W}, 649 \mathrm{~m}$ altitude, using the soil sprinkling method of Duddington (1955), modified by Santos et al. (1991). Fungi were kept in test tubes containing $2 \%$ cornmeal agar ( $2 \% \mathrm{CMA})$, in the dark, at $4^{\circ} \mathrm{C}$ for 10 days.

\section{Conidia collection}

Culture discs ( $4 \mathrm{~mm}$ in diameter) were removed from the fungal isolates kept in test tubes containing $2 \%$ CMA and transferred to $9.0 \mathrm{~cm}$ Petri dishes containing $20 \mathrm{ml}$ of $2 \%$ potato dextrose agar and kept at $25^{\circ} \mathrm{C}$ in the dark for 10 days. After growth, new culture discs $(4 \mathrm{~mm}$ in diameter) were transferred to $9.0 \mathrm{~cm}$ diameter Petri dishes containing $20 \mathrm{ml}$ of $2 \%$ water-agar $(2 \% \mathrm{WA})$ and $1 \mathrm{ml}$ of distilled water containing 1000 larvae of Panagrellus sp. was added daily for 21 days to induce conidia formation. When fungal development was complete, $5 \mathrm{ml}$ of distilled water were added to each Petri dish, and the conidial and mycelial fragments were removed as described by Araújo et al. (1993).

\section{$L_{1}$ Angiostrongylus vasorum}

The strain used in the assays was originally isolated from faeces of two naturally infected dogs, from the city of Caratinga, Minas Gerais (Lima et al., 1985). This strain has been maintained by successive passages in dogs. Faeces of infected dogs were collected and placed in a modified Baermann funnel for $12 \mathrm{~h}$, for $L_{1}$ recovery (Barçante et al., 2003a, b). After this period, the tube was removed and $200 \mathrm{~g}$ were centrifuged for $2 \mathrm{~min}$. The supernatant was discarded and the pellet containing $A$. vasorum $\mathrm{L}_{1}$ was resuspended in $5 \mathrm{ml}$ of $0.85 \%$ saline solution. The content was homogenized and three $10 \mu \mathrm{l}$ aliquots were removed and distributed on $7.5 \times 2.5 \mathrm{~cm}$ glass slides. Larval counts were carried out under a stereomicroscope $(25 \times)$. The total larval number was estimated by a simple rule of three. 


\section{Experimental assay}

Treatments consisted of four groups of fungal isolates and a control without fungus plated in $9.0 \mathrm{~cm}$ Petri dishes containing $20 \mathrm{ml}$ of $2 \%$ WA, with six repetitions each. Petri dishes were previously marked into $4 \mathrm{~mm}$ diameter fields. A total of 1000 A. vasorum $\mathrm{L}_{1}$ larvae were plated with 1000 conidia of one of the fungal isolates AC001, NF34, SF53 or I31 in 2\% WA. The control group (without fungus) contained $1000 \mathrm{~L}_{1}$ larvae plated with $2 \%$ WA only.

Ten random fields ( $4 \mathrm{~mm}$ diameter) were examined per plate of treated and control groups, every $24 \mathrm{~h}$ for 7 days under an optical microscope $(10 \times$ and $40 \times$ objective lens) for non-predated $\mathrm{L}_{1}$ counts. After 7 days, the nonpredated $L_{1}$ were recovered from the Petri dishes using the Baermann method.

\section{Statistical analysis}

Means of recovered A. vasorum $\mathrm{L}_{1}$ were calculated. Data were examined by analysis of variance at significance levels of 1 and 5\% probability (Ayres et al., 2003). Predation efficiency of $\mathrm{L}_{1}$ relative to the control group was evaluated by the Tukey's test at $1 \%$ probability. The reduction percentage of $\mathrm{L}_{1}$ means was calculated according to the following equation: Reduction $\%=$ (Average of $\mathrm{L}_{1}$ recovered from control group - Average of $L_{1}$ recovered from treatment groups) $\times 100 /$ Average of $\mathrm{L}_{1}$ recovered from the control group.

\section{Results}

The tested isolates of predatory fungi $D$. flagrans (AC001), M. thaumasium (NF34), M. sinense (SF53) and A. robusta (I31) were able to capture $A$. vasorum $\mathrm{L}_{1}$ in the experimental in vitro test.

No difference was found $(P>0.05)$ in the comparison between capture and destruction of $A$. vasorum $\mathrm{L}_{1}$ in Petri dishes of the groups treated with isolates of $D$. flagrans (AC001), M. thaumasium (NF34), M. sinense (SF53) and A. robusta (I31) during the experimental assay (table 1), but there was difference $(P<0.05)$ between the means of non-predated $A$. vasorum $\mathrm{L}_{1}$ per $4 \mathrm{~mm}$ diameter field in the Petri dishes of the control group compared to means of $L_{1}$ recorded in the groups treated with the fungi throughout the experiment. The recorded reduction percentages of $A$. vasorum $\mathrm{L}_{1}$ were $80.3 \%$ (AC001) $74.5 \%$ (NF34), 74.2\% (SF53) and 71.8\% (I31).

The presence of $A$. vasorum $\mathrm{L}_{1}$ in Petri dishes containing $2 \%$ WA was essential for trap formation by the fungal isolates, since this culture medium is nutritionally poor (fig. 1A and B). The presence of nematophagous fungi was not observed in the control group during the experiment. Evidence of predation was confirmed by the means of recovered $A$. vasorum $\mathrm{L}_{1}$ using the Baermann method at 7 days post-plating, at the end of the experiment (fig. 2).

The linear regression coefficients calculated by the analysis of $A$. vasorum $\mathrm{L}_{1}$ means per $4 \mathrm{~mm}$ diameter field of the treated and control groups were: -0.075 (AC001); -0.190 (NF34); -0.311 (SF53); -0.256 (I31) and -0.282 (control group).

\section{Discussion}

The genera Ancylostoma and Toxocara, parasites of dogs and cats, and possibly the species Angiostrongylus vasorum, stand out among helminths with zoonotic potential. Besides showing medical-veterinary importance, $A$. vasorum as a cardiopulmonary parasite of domestic and wild dogs also requires special attention and investigation because it can also infect humans (Eckert \& Lämmler, 1972; Lima et al., 1994).

Nematophagous fungi, especially the genera Duddingtonia, Monacrosporium and Arthrobotrys, have predatory capacity on infective larvae $\left(\mathrm{L}_{3}\right)$ of gastrointestinal nematode parasites of domestic animals (Araújo et al., 2004b, 2006; Campos et al., 2007). These genera are recognized only as predators, and the predatory capacity of the species $D$. flagrans and $M$. thaumasium, $M$. sinense and $A$. robusta has been thoroughly discussed and proved in the control of $\mathrm{L}_{3}$ of gastrointestinal nematode parasites of ruminants, horses and small ruminants (Castro et al., 2003; Chandrawathani et al., 2004; Araújo et al., 2006, 2007; Dias et al., 2007). However, the predatory capacity of these species had never been tested on larvae of $A$. vasorum. This is the first work on the interaction of the fungi $D$. flagrans, $M$. thaumasium, $M$. sinense and $A$. robusta with A. vasorum $\mathrm{L}_{1}$ larvae. Few studies have mentioned the in vitro predatory activity of different nematophagous

Table 1. Daily means and standard deviations of non-predated first-stage larvae $\left(\mathrm{L}_{1}\right)$ of Angiostrongylus vasorum per $4 \mathrm{~mm}$ diameter field in $2 \%$ water-agar during 7 days of treatment with the fungal isolates Duddingtonia flagrans (AC001), Monacrosporium thaumasium (NF34), Monacrosporium sinense (SF53), Arthrobotrys robusta (I31) and control without fungus.

\begin{tabular}{lccccc}
\hline & \multicolumn{5}{c}{ Treatment } \\
\cline { 2 - 6 } Time (days) & AC001 & NF34 & SF53 & I31 & Control \\
\hline 1 & $0.98 \pm 2.04 \mathrm{a}$ & $1.23 \pm 3.07 \mathrm{a}$ & $2.10 \pm 3.50 \mathrm{a}$ & $2.73 \pm 4.22 \mathrm{a}$ & $14.73 \mathrm{~b} \pm 6.81$ \\
2 & $2.59 \pm 4.12 \mathrm{a}$ & $4.34 \pm 4.99 \mathrm{a}$ & $2.32 \pm 3.32 \mathrm{a}$ & $1.80 \pm 3.29 \mathrm{a}$ & $23.51 \mathrm{~b} \pm 13.02$ \\
3 & $0.40 \pm 0.78 \mathrm{a}$ & $1.15 \pm 1.51 \mathrm{a}$ & $0.58 \pm 0.96 \mathrm{a}$ & $0.93 \pm 1.05 \mathrm{a}$ & $14.20 \mathrm{~b} \pm 6.31$ \\
4 & $0.68 \pm 1.62 \mathrm{a}$ & $1.02 \pm 1.94 \mathrm{a}$ & $0.54 \pm 1.16 \mathrm{a}$ & $1.02 \pm 1.72 \mathrm{a}$ & $12.10 \mathrm{~b} \pm 6.66$ \\
5 & $0.41 \pm 1.24 \mathrm{a}$ & $1.05 \pm 1.26 \mathrm{a}$ & $0.39 \pm 0.70 \mathrm{a}$ & $0.98 \pm 1.37 \mathrm{a}$ & $12.90 \mathrm{~b} \pm 9.22$ \\
6 & $0.88 \pm 1.99 \mathrm{a}$ & $1.51 \pm 2.54 \mathrm{a}$ & $0.54 \pm 1.53 \mathrm{a}$ & $0.66 \pm 2.02 \mathrm{a}$ & $11.39 \mathrm{~b} \pm 6.74$ \\
7 & $1.33 \pm 2.70 \mathrm{a}$ & $1.38 \pm 2.65 \mathrm{a}$ & $0.45 \pm 0.68 \mathrm{a}$ & $1.08 \pm 1.87 \mathrm{a}$ & $11.28 \mathrm{~b} \pm 8.71$ \\
\hline
\end{tabular}

Means followed by the same small letter in the rows were not statistically different $(P>0.05)$. 

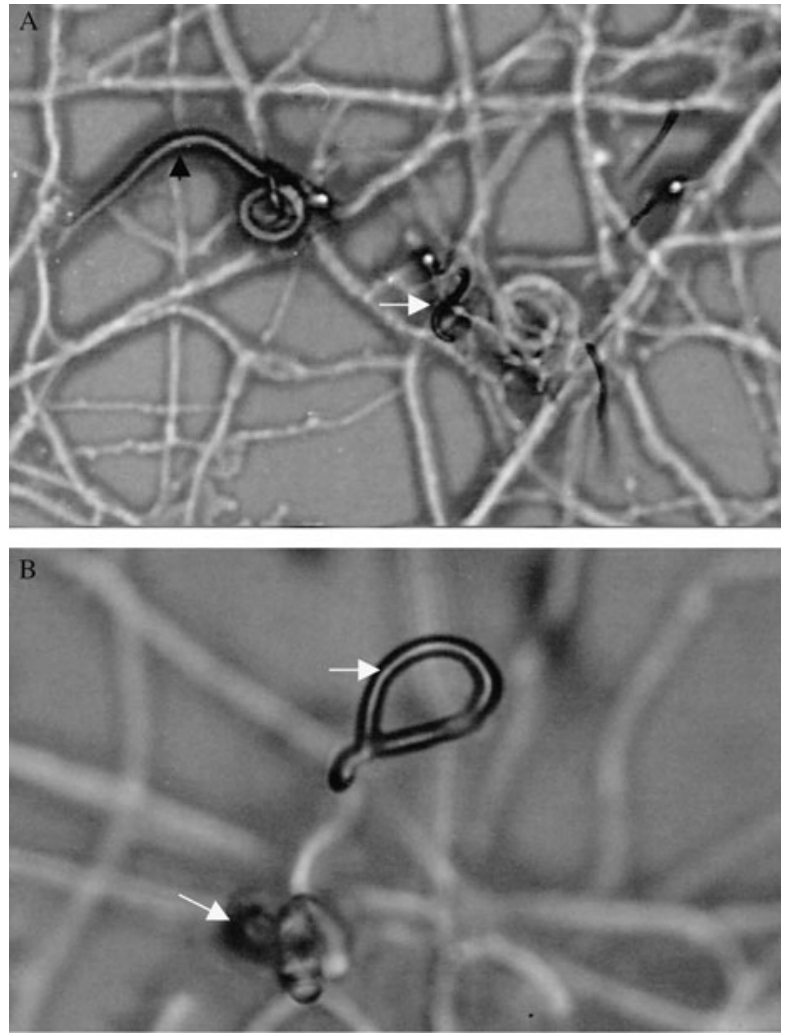

Fig. 1. Angiostrongylus vasorum first-stage larvae $\left(\mathrm{L}_{1}\right)$ captured by Duddingtonia flagrans (black arrow) in Petri dishes containing $2 \%$ water-agar, and trap formation by the fungal isolate $D$. flagrans (white arrow). Magnification: (A) $10 \times$ and (B) $40 \times$ objective lens.

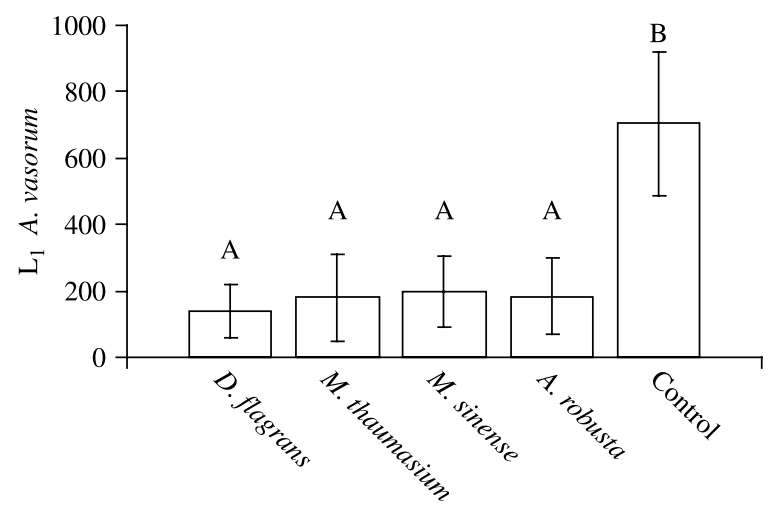

Fungal isolates

Fig. 2. Mean number of non-predated Angiostrongylus vasorum first-stage larvae $\left(\mathrm{L}_{1}\right)$ recovered in $2 \%$ water-agar by the Baermann method on the seventh treatment day after interaction with the fungal isolates Duddingtonia flagrans (AC001), Monacrosporium thaumasium (NF34), Monacrosporium sinense (SF53), Arthrobotrys robusta (I31) and control (without fungus). Lines on bars represent standard deviation. Means followed by at least one common capital letter (A) in the row are not significantly different by Tukey's test at a 5\% probability level. fungi on larvae of nematode parasites of dogs (Maciel et al., 2006a, b).

In the present work, although the isolate (I31) from $A$. robusta was effective in reducing $A$. vasorum $\mathrm{L}_{1}$ with reduction percentage of $71.8 \%$, D. flagrans (AC001) was found to be more efficient compared with the others and at the end of 7 days showed a higher reduction percentage $(80.31 \%)$. These results showed that $D$. flagrans (AC001) had higher in vitro predatory activity on $A$. vasorum $\mathrm{L}_{1}$.

Eren \& Pramer (1965) reported on the regular supply of nematodes to fungi in nutritionally poor culture media, which reduces fungal saprophytic growth. For this reason, in this study we used only $2 \%$ WA, a low nutrient culture medium, to reduce the saprophytic growth of fungal isolates, providing $A$. vasorum $\mathrm{L}_{1}$ as a single nutritional source. The higher the mobility of nematodes, the greater the stimulus to trap production (Nansen et al., 1988). This phenomenon was observed in this study, as trap formation and $\mathrm{L}_{1}$ predation by the fungal isolates were recorded during the first observation, $24 \mathrm{~h}$ after interaction (fig. 1). Maciel et al. (2006b) found that in $2 \%$ WA, the isolate $A$. robusta (I31) showed higher predatory activity on Ancylostoma spp. $\mathrm{L}_{3}$ compared with isolates D. flagrans (CG768) and M. thaumasium (NF34). However, in the present study, the isolate D. flagrans (AC001) in $2 \%$ WA showed the highest in vitro predatory activity on A. vasorum $\mathrm{L}_{1}$ at the end of the experiment.

Negative coefficients of correlation indicate a downward behaviour of the regression curves for the treatments with the fungal isolates AC001, NF34, SF53 and I31. This was caused by the reduction in the means of non-predated $A$. vasorum $\mathrm{L}_{1}$ per $4 \mathrm{~mm}$ diameter field during the experimental assay, mainly by the capture of $\mathrm{L}_{1}$ in fungal traps. Reduction in the number of $\mathrm{L}_{1}$ per $4 \mathrm{~mm}$ diameter field in the control group, during the study, was caused by larval migration to the periphery of the Petri dishes, where the moisture level was higher, which was also reported by Araújo et al. (2006) in an in vitro assay carried out in Petri dishes.

The results of this study confirm previous work on the efficiency of nematophagous fungi in the control of larvae of nematode parasites of dogs. This allows us to conclude that the fungi $D$. flagrans, $M$. thaumasium, $M$. sinense and A. robusta have predatory activity on first-stage larvae of A. vasorum and that this is a likely alternative method for biological control of $A$. vasorum larvae.

\section{References}

Araújo, J.V., Santos, M.A., Ferraz, S. \& Maia, A.S. (1993) Antagonistic effect of predacious Arthrobotrys fungi on infective Haemonchus placei larvae. Journal of Helminthology 67, 136-138.

Araújo, J.V., Gomes, A.P.S. \& Guimarães, M.P. (1998) Biological control of bovine gastrointestinal nematode parasites in southern Brazil by the nematode-trapping fungus Arthrobotrys robusta. Revista Brasileira de Parasitologia Veterinária 7, 117-122.

Araújo, J.V., Stephano, M.A. \& Sampaio, W.M. (2000) Effects of temperature, mineral salt and passage 
through gastrointestinal tract of calves on alginate formulation of Arthrobotrys robusta - a nematodetrapping fungus. Revista Brasileira de Parasitologia Veterinária 9, 55-60.

Araújo, J.V., Mota, M.A. \& Campos, A.K. (2004a) Controle biológico de helmintos parasitos de animais por fungos nematófagos. Revista Brasileira de Parasitologia Veterinária 13, 165-170.

Araújo, J.V., Assis, R.C.L., Campos, A.K. \& Mota, M.A. (2004b) Atividade in vitro dos fungos nematófagos dos gêneros Arthrobotrys, Duddingtonia e Monacrosporium sobre nematóides trichostrongilídeos (Nematoda: Trichostrongyloidea) parasitos gastrintestinais de bovinos. Revista Brasileira de Parasitologia Veterinária 13, 65-71.

Araújo, J.V., Freitas, B.W., Vieira, T.C. \& Campos, A.K. (2006) Avaliação do fungo predador de nematóides Duddingtonia flagrans sobre larvas infectantes de Haemonchus contortus e Strongyloides papillosus de caprinos. Revista Brasileira de Parasitologia Veterinária 15, 76-79.

Araújo, J.V., Rodrigues, M.L.A., Silva, W.W. \& Vieira, L.S. (2007) Controle biológico de nematóides gastrintestinais de caprinos em clima semi-árido pelo fungo Monacrosporium thaumasium. Pesquisa Agropecuária Brasileira 42, 1177-1181.

Araújo, J.V., Braga, F.R., Araújo, J.M., Silva, A.R. \& Tavela, A.O. (2008) In vitro evaluation of the effect of the nematophagous fungi Duddingtonia flagrans, Monacrosporium sinense and Pochonia chlamydosporia on Ascaris suum eggs. Parasitology Research 102, 787-790.

Ayres, M., Ayres, J.R.M., Ayres, D.L. \& Santos, A.S. (2003) Aplicações estatísticas nas áreas de ciências biológicas. 290 pp. Brasília.

Barçante, J.M.P., Barçante, T.A., Dias, S.R.C., Vieira, L.Q., Lima, W.S. \& Negrão-Corrêa, D. (2003a) A method to obtain axenic Angiostrongylus vasorum firststage larvae from dog feces. Parasitology Research 89, 89-93.

Barçante, T.A., Barçante, J.M.P., Dias, S.R.C. \& Lima, W.S. (2003b) Angiostrongylus vasorum (Baillet 1866) Kamensky 1905: emergence of third-stage larvae from Biomphalaria glabrata infected snails. Parasitology Research 91, 471-475.

Bolt, G., Monrad, J., Frandsen, F., Henrikesen, P. \& Dietz, H.H. (1993) The common frog (Rana temporaria) as a potential paratenic and intermediate host for Angiostrongylus vasorum. Parasitology Research 79, 428-430.

Braga, F.R., Araújo, J.V., Campos, A.K., Carvalho, R.O., Silva, A.R., Tavela, A.O. \& Maciel, A.S. (2007) Observação in vitro da ação dos isolados fúngicos Duddingtonia flagrans, Monacrosporium thaumasium e Verticillium chlamydosporium sobre ovos de Ascaris lumbricoides (Lineu, 1758). Revista da Sociedade Brasileira de Medicina Tropical 40, 356-358.

Campos, A.K., Araújo, J.V., Assis, R.C.L., Granda, J.R. \& Guimarães, M.P. (2007) Viabilidade de formulação peletizada do fungo nematófago Monacrosporium sinense, no controle biológico de nematóides parasitos gastrintestinais de bezerros. Arquivo Brasileiro de Medicina Veterinária e Zootecnia 59, 14-20.
Castro, A.A., Oliveira, C.R.C., Anjos, D.H.S., Ornellas, E.I., Bittencourt, V.R.E.P., Araújo, J.V., Sampaio, I.B.M. \& Rodrigues, M.L.A. (2003) Potencial dos fungos nematófagos Arthrobotrys sp. e Monacrosporium thaumasium para o controle de larvas de ciatostomíneos de eqüinos (Nematoda: Cyathostominae). Revista Brasileira de Parasitologia Veterinária 12, 53-57.

Chandrawathani, P., Jamnah, O., Adman, M., Waller, P.J., Larsen, M. \& Gillespie, A.T. (2004) Field studies on the biological control of nematode parasites of sheep in the tropics, using the microfungus Duddingtonia flagrans. Veterinary Parasitology 120, 177-187.

Cury, M.C. \& Lima, W.S. (1995) Ocorrência de Angiostrongylus vasorum no rim de cão experimentalmente infectados. Arquivo Brasileiro de Medicina Veterinária e Zootecnia 47, 593-595.

Cury, M.C. \& Lima, W.S. (2002) Helmintos de cães e gatos. Cadernos Técnicos de Veterinária e Zootecnia 39, 12-35.

Cury, M.C., Gumarães, M.P., Lima, W.S., Caldeira, M.C.M., Couto, T.R., Murta, K., Carvalho, M.G. \& Baptista, J.M.B. (2002) Biochemical serum profiles in dogs experimentally infected with Angiostrongylus vasorum (Baillet, 1866). Veterinary Parasitology 128, $121-127$.

Dias, A.S., Araújo, J.V., Campos, A.K., Braga, F.R. \& Fonseca, T.A. (2007) Application of a formulation of the nematophagous fungus Duddingtonia flagrans in the control of cattle gastrointestinal nematodioses. World Journal of Microbiology and Biotechnology 23, 1245-1252.

Duddington, C.L. (1955) Notes on the technique of handling predaceous fungi. Transactions of British Mycology Society 38, 97-103.

Eckert, J. \& Lämmler, G. (1972) Angiostrongylose bei Mensch und Tier. Parasitology Research 39, 303-322.

Eren, J. \& Pramer, D. (1965) The most probable number of nematode-trapping fungi in soil. Soil Science 99, 285.

Gray, N.F. (1987) Nematophagous fungi with particular reference to their ecology. Biological Reviews 62, 245-304.

Griffin, D.H. (1994) Fungal physiology. 458 pp. New York, Wiley-Liss.

Guilhon, J. \& Cens, B. (1973) Angiostrongylus vasorum (Baillet, 1866) Etude biologique et morfologique. Annales de Parasitologie Humaine et Comparée 48, 567-596.

Lima, W.S., Costa, H.M.A., Guimarães, M.P. \& Leite, A.C.R. (1985) Angiostrongylus vasorum (Baillet, 1866) Nematoda: Prothostrongylidae em cães de Minas Gerais, Brasil. Memórias do Instituto Oswaldo Cruz 80, 233-235.

Lima, W.S., Guimarães, M.P. \& Lemos, I.S. (1994) Occurrence of Angiostrongylus vasorum in the lungs of Brazilian fox Dusicyon vetulus. Journal Helminthology 68, 87.

Maciel, A.S., Araújo, J.V. \& Cecon, P.R. (2006a) In vitro predatory activity of fungi Arthrobotrys robusta, Duddingtonia flagrans and Monacrosporium thaumasium on infective larvae of Ancylostoma spp. of dogs. Revista Brasileira de Parasitologia Veterinária 15, 71-75.

Maciel, A.S., Araújo, J.V. \& Campos, A.K. (2006b) Viability of nematophagous fungi Arthrobotrys robusta, Duddingtonia flagrans and Monacrosporium thaumasium after sporulation in differents culture means. Revista Brasileira de Parasitologia Veterinária 15, 182-187. 
Mota, M.A., Campos, A.K. \& Araújo, J.V. (2003) Controle biológico de helmintos parasitos de animais: estágio atual e perspectivas futuras. Pesquisa Veterinária Brasileira 23, 93-100.

Nansen, P., Foldager, J., Hansen, J., Henriksen, S.A. \& Jorgensen, R.J. (1988) Grazing and acquisition of Ostertagia ostertagi in calves. International Journal for Parasitology 27, 325-335.

Nordbring-Hertz, B., Jansson, H.B. \& Tunlid, A. (2002) Nematophagous fungi. pp. 681-690 in Encyclopedia of life sciences, vol. 12. Basingstoke, Macmillan Publishers.

Oliveira, S.D. Jr, Barçante, J.M.P., Barçante, T.A., Dias, S.R.C. \& Lima, W.S. (2005) Larval output of infected and re-infected dogs with Angiostrongylus vasorum (Baillet, 1866) Kamensky, 1905. Veterinary Parasitology 141, 101-106.

Patteson, M.W., Gibbs, C., Wotton, P.R. \& Day, M.J. (1993) Angiostrongylus vasorum infection in seven dogs. Veterinary Record 4, 565-570.
Ribieri, T., Gottstein, B., Huber, E., Welle, M., Foster, J.L. \& Grosclaude, P.A. (2001) Case of canine angiostrongylosis. Schweizer Archiv fürTierheilkunde 143, 313-318.

Rocha, R.A., Araujo, A.V. \& Amarante, A.F.T. (2007) Efficacy of the nematode-trapping fungus Duddingtonia flagrans against infections by Haemonchus and Trichostrongylus species in lambs at pasture. Journal of Helminthology 81, 387-392.

Saeed, I., Maddox-Hyttel, C., Monrad, J. \& Kapel, C.M.O. (2006) Helminths of red fox (Vulpes vulpes) in Denmark. Veterinary Parasitology 139, 168-179.

Santos, M.A., Ferraz, S. \& Muchove, J. (1991) Detection and ecology of nematophagous fungi from Brazilian soils. Nematologia Brasileira 15, 121-134.

Thiengo, S.C. (1996) Mode of infection of Sarasinula marginata (Mollusca) with larvae of Angiostrongylus costaricensis. Memórias do Instituto Oswaldo Cruz 91, 277-278. 